\title{
Front Matter: Volume 10102
}

, "Front Matter: Volume 10102," Proc. SPIE 10102, Ultrafast Phenomena and Nanophotonics XXI, 1010201 (9 May 2017); doi: 10.1117/12.2276629

SPIE. Event: SPIE OPTO, 2017, San Francisco, California, United States 


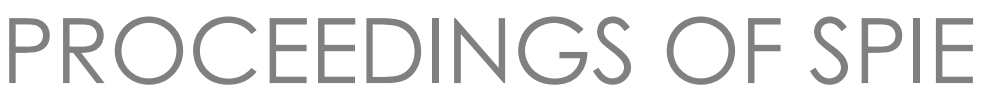

\title{
Ultrafast Phenomena and Nanophotonics XXI
}

\author{
Markus Betz \\ Abdulhakem Y. Elezzabi \\ Editors
}

30 January-2 February 2017

San Francisco, California, United States

Sponsored by

SPIE

Cosponsored by

Spectra-Physics, (United States)

Published by

SPIE 
The papers in this volume were part of the technical conference cited on the cover and title page. Papers were selected and subject to review by the editors and conference program committee. Some conference presentations may not be available for publication. Additional papers and presentation recordings may be available online in the SPIE Digital Library at SPIEDigitallibrary.org.

The papers reflect the work and thoughts of the authors and are published herein as submitted. The publisher is not responsible for the validity of the information or for any outcomes resulting from reliance thereon.

Please use the following format to cite material from these proceedings:

Author(s), "Title of Paper," in Ultrafast Phenomena and Nanophotonics XXI, edited by Markus Betz, Abdulhakem Y. Elezzabi, Proceedings of SPIE Vol. 10102 (SPIE, Bellingham, WA, 2017) Seven-digit Article CID Number.

ISSN: 0277-786X

ISSN: 1996-756X (electronic)

ISBN: 9781510606456

ISBN: 9781510606463 (electronic)

Published by

SPIE

P.O. Box 10, Bellingham, Washington 98227-0010 USA

Telephone +1 3606763290 (Pacific Time) · Fax +1 3606471445

SPIE.org

Copyright @ 2017, Society of Photo-Optical Instrumentation Engineers.

Copying of material in this book for internal or personal use, or for the internal or personal use of specific clients, beyond the fair use provisions granted by the U.S. Copyright Law is authorized by SPIE subject to payment of copying fees. The Transactional Reporting Service base fee for this volume is $\$ 18.00$ per article (or portion thereof), which should be paid directly to the Copyright Clearance Center (CCC), 222 Rosewood Drive, Danvers, MA 01923. Payment may also be made electronically through CCC Online at copyright.com. Other copying for republication, resale, advertising or promotion, or any form of systematic or multiple reproduction of any material in this book is prohibited except with permission in writing from the publisher. The CCC fee code is 0277-786X/17/\$18.00.

Printed in the United States of America.

Publication of record for individual papers is online in the SPIE Digital Library.

\section{SPIE. DIGITAL}

Paper Numbering: Proceedings of SPIE follow an e-First publication model. A unique citation identifier (CID) number is assigned to each article at the time of publication. Utilization of CIDs allows articles to be fully citable as soon as they are published online, and connects the same identifier to all online and print versions of the publication. SPIE uses a seven-digit CID article numbering system structured as follows:

- The first five digits correspond to the SPIE volume number.

- The last two digits indicate publication order within the volume using a Base 36 numbering system employing both numerals and letters. These two-number sets start with 00, 01, 02, 03, 04, $05,06,07,08,09,0 A, 0 B \ldots$. OZ, followed by 10-1Z, 20-2Z, etc. The CID Number appears on each page of the manuscript. 


\title{
Contents
}

\author{
vii Authors \\ ix Conference Committee
}

\section{NANOPLASMONICS}

1010203 Optical slot antenna and its application (Invited Paper) [10102-2]

1010204 Electrically driven optical antennas enabled by mesoscopic contacts (Invited Paper) [10102-3]

STRONG AND ULTRASTRONG FIELD PHENOMENA IN SOLIDS

1010207 Dynamical control of optical properties by using a terahertz dressed state (Invited Paper) [10102-6]

1010208 Ultrafast nonlinear and strong-field phenomena in silicon-loaded nanoplasmonic waveguides (Invited Paper) [10102-7]

\section{ULTRAFAST SPIN DYNAMICS AND SPIN MANIPULATION}

10102 OD Polariton formalism for semiconductor double microcavities [10102-12]

ULTRAFAST PHENOMENA IN 2D MATERIALS I

10102 Ol Ultrafast extreme-ultraviolet ARPES studies of electronic dynamics in two-dimensional materials (Invited Paper) [10102-17]

10102 0J Ultrafast carrier dynamics of epitaxial silicene [10102-18]

\section{ULTRAFAST AND NONLINEAR NANOPLASMONICS I}

1010200 High-speed polarization modulation in a hybrid ridge-plasmonic waveguide [10102-23]

FEMTOSECOND PHOTOCURRENTS FROM SURFACES AND NANOSTRUCTURES

10102 OP A microscopic approach to ultrafast near band gap photocurrents in bulk semiconductors (Invited Paper) [10102-24] 
$101020 Q \quad$ Momentum space view of the ultrafast dynamics of surface photocurrents on topological insulators (Invited Paper) [10102-25]

10102 OS Lowering the barrier for photoemission in eCarbon/Au bilayer driven by a plasmonic field [10102-27]

\section{TERAHERTZ SPECTROSCOPY}

10102 OT Exciton Mott transition in GaAs studied by terahertz spectroscopy (Invited Paper) [10102-28]

\section{COHERENT AND NONLINEAR DYNAMICS OF OPTICAL EXCITATION}

1010211 Four-wave mixing response of solution-processed $\mathrm{CH}_{3} \mathrm{NH}_{3} \mathrm{Pbl}_{3}$ thin films (Invited Paper) [10102-36]

1010213 Unraveling electron and hole relaxation dynamics in colloidal CdTe nanorods: a twodimensional electronic spectroscopy study [10102-38]

1010215 Dynamic stabilization of a polariton Rabi oscillator in the ground and inverted stationary states [10102-40]

NONLINEAR OPTICAL EFFECTS

10102 1B Influence of SOD on THG for femtosecond laser pulse [10102-46]

10102 1C Non-perturbative twist of attosecond extreme-ultraviolet vortex beams [10102-66]

ULTRAFAST PHENOMENA IN 2D MATERIALS II

10102 1E Control of interlayer valley excitons in atomically-thin MoSe 2 -WSe2 heterostructures (Invited Paper) [10102-48]

10102 IF Excitonic linewidth and coherence lifetime in monolayer transition metal dichalcogenides [10102-49]

\section{ULTRAFAST ACOUSTICS, NANOMECHANICS, AND PHOTOCATALYSIS}

$101021 \mathrm{~L} \quad$ Ultrafast carrier dynamics unravel role of surface ligands and metal domain size on the photocatalytic hydrogen evolution efficiency of Au-tipped CdS nanorods: an ultrafast transient absorption spectroscopy study [10102-55] 
ULTRAFAST SPECTROSCOPY AND MANIPULATION OF MONOLAYERS AND 2D MATERIALS

$101021 \mathrm{U}$ High harmonic generation in graphene: temporal and spectral properties [10102-67]

POSTER SESSION

$101021 \mathrm{~W}$ Interferometric measurement of refractive index modification in a single mode microfiber [10102-65] 


\section{Authors}

Numbers in the index correspond to the last two digits of the six-digit citation identifier (CID) article numbering system used in Proceedings of SPIE. The first four digits reflect the volume number. Base 36 numbering is employed for the last two digits and indicates the order of articles within the volume. Numbers start with 00, 01, 02, 03, 04, 05, 06, 07, 08, 09, OA, OB...0Z, followed by 10-12, 20-2Z, etc.

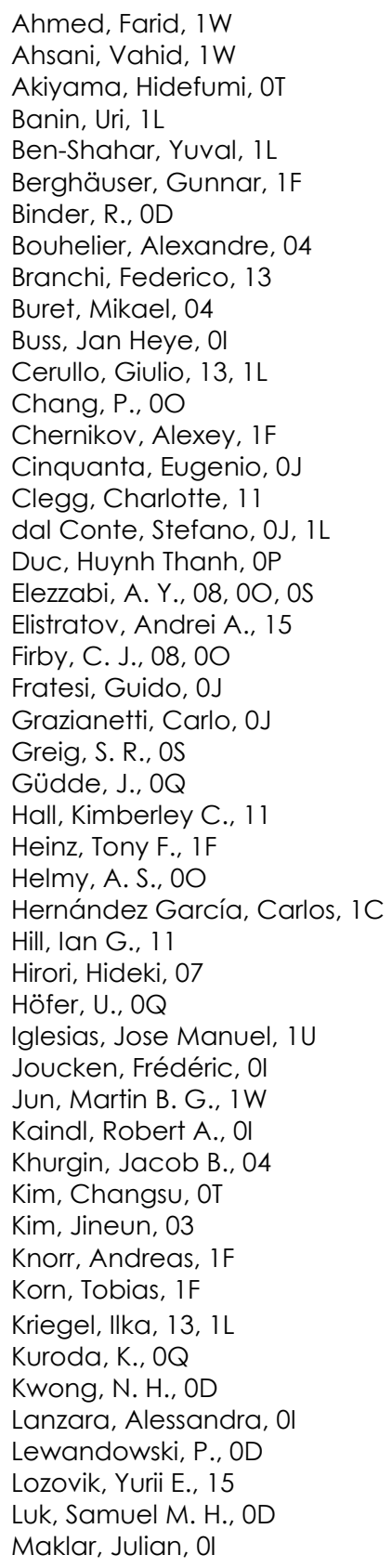

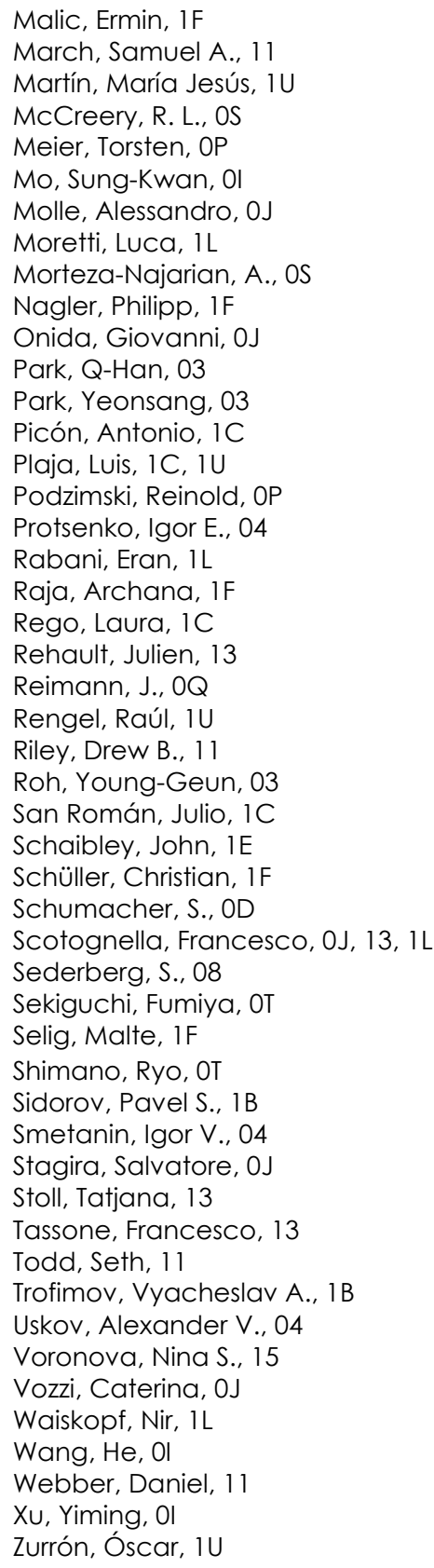




\title{
Conference Committee
}

\author{
Symposium Chairs
}

Jean-Emmanuel Broquin, IMEP-LAHC (France)

Shibin Jiang, AdValue Photonics, Inc. (United States)

Symposium Co-chairs

Connie J. Chang-Hasnain, University of California, Berkeley

(United States)

Graham T. Reed, Optoelectronics Research Centre, University of

Southampton (United Kingdom)

Program Track Chair

James G. Grote, Air Force Research Laboratory (United States)

Conference Chairs

Markus Betz, Technische Universität Dortmund (Germany)

Abdulhakem Y. Elezzabi, University of Alberta (Canada)

Conference Program Committee

Alan D. Bristow, West Virginia University (United States)

Kazuhiko Hirakawa, The University of Tokyo (Japan)

Rupert Huber, Universität Regensburg (Germany)

Robert A. Kaindl, Lawrence Berkeley National Laboratory (United States)

Dai-Sik Kim, Seoul National University (Korea, Republic of)

Xiaoqin Li, The University of Texas at Austin (United States)

Christoph Lienau, Carl von Ossietzky Universität Oldenburg (Germany)

Torsten Meier, Universität Paderborn (Germany)

Walter Pfeiffer, Universität Bielefeld (Germany)

Pascal Ruello, Université du Maine (France)

Volker J. Sorger, The George Washington University (United States)

Fabrice Vallee, Université Claude Bernard Lyon 1 (France)

Session Chairs

1 Nanoplasmonics

Markus Betz, Technische Universität Dortmund (Germany) 
2 Strong and Ultrastrong Field Phenomena in Solids

Abdulhakem Y. Elezzabi, University of Alberta (Canada)

3 Ultrafast Spin Dynamics and Spin Manipulation

Mark I. Stockman, Georgia State University (United States)

4 Ultrafast Phenomena in 2D Materials I

Shawn Greig, University of Alberta (Canada)

5 Ultrafast and Nonlinear Nanoplasmonics I

Walter Pfeiffer, Universität Bielefeld (Germany)

6 Femtosecond Photocurrents from Surfaces and Nanostructures

Fabrice Vallee, Université Claude Bernard Lyon 1 (France)

7 Terahertz Spectroscopy

Torsten Meier, Universität Paderborn (Germany)

8 Coherent and Nonlinear Dynamics of Optical Excitation

Alan D. Bristow, West Virginia University (United States)

9 Sub-cycle and Attosecond Physics

Denis Karaiskaj, University of South Florida (United States)

10 Nonlinear Optical Effects

Tenio Popmintchev, JILA (United States)

11 Ultrafast Phenomena in 2D Materials II

Alfred Leitenstorfer, Universität Konstanz (Germany)

12 Ultrafast Acoustics, Nanomechanics, and Photocatalysis

Thomas Zentgraf, Universität Paderborn (Germany)

13 Ultrafast and Nonlinear Nanoplasmonics II

Curtis Firby, University of Alberta (Canada)

14 Ultrafast Spectroscopy and Manipulation of Monolayers and 2D Materials

Abdulhakem Y. Elezzabi, University of Alberta (Canada) 